\title{
Kunsten å revitalisere gjenstanden som fascinasjonsobjekt
}

\author{
Kristine Orestad SørgaARD
}

Det er lenge siden publikum strømmet til museene for å se på eksotiske planter, utstoppede dyr og kuriositeter fra fjerne himmelstrøk. Grunnen til det er selvsagt at mediene er $\mathrm{i}$ stand til å bringe mer representative bilder av omverdenen inn $\mathrm{i}$ vår egen stue. I denne artikkelen spør forfatteren om museene er $i$ ferd med å bli utkonkurrert av det moderne billedmediets realisme. Har museumsutstillingene en fremtid? Er det mulig å revitalisere gjenstanden som fascinasjonsobjekt? $0 \mathrm{~g}$ hva er de praktiske konsekvensene av en gjenstandsbasert formidlingsstrategi?

Begrepet "museum" kan føres tilbake til det greske ordet "mouseion" som skal ha vært navnet på en forskningsinstitusjon og et kunnskapssentrum i Alexandria, grunnlagt av den egyptiske kongen Ptolemy Soter ca. 290 f. Kr. Det er imidlertid først på 1400-tallet, i renessansens Europa, at forløperen til det moderne museet oppstår som et Kunstkammer, Wunderkammer eller Kuriositetskabinett. De tidlige kuriositetskabinettene ble etablert i kretsen rundt konger, fyrster og andre adelige personer, og var først og fremst åpne for medlemmer av samfunnets øverste sjikt. Kuriositetskabinettene kunne inneholde alt fra planter og mineraler til bøker, skulpturer, mynter, instrumenter og en rekke andre spektakulære og ekstraordinære objekt. De skulle ikke bare synliggjøre det fantastiske ved Guds skaperverk, men også gjenspeile eierens makt, dannelse og analytiske intellekt. "Not only was nature created for man, but its recording, analysis and investigation presented the highest goal of all human activity" (Schulz 1994: 176).

I løpet av 1800-tallet vokste det moderne museum frem som et folkeopplysningsprosjekt og ble del av en ny offentlig sfære. Gjennom selektive og velorganiserte utstillinger ble samlingene gjort tilgjengelige for det bredere lag av folket. En del av målsettingen til det moderne museet var også å vise at gjenstandene inngikk som typer $i$ et ordnet univers. Museene skulle ikke bare synliggjøre de eksotiske aspektene ved gjenstandssamlingen, men fokusere på det som var lovmessig og typisk ved hvert objekt.

Governed by the new principles of scientific taxonomy, the stress was placed on the observable differences between things rather than their hidden resemblances: the common or ordinary object, accorded a repre- 
sentative function, was accorded priority over the exotic or unusual; and things were arranged as parts of series rather than unique items (Bennett 1995: 96).

Det nye, ideologiske grunnlaget for museene var helt i tråd med de tankemessige strømningene $\mathrm{i}$ humanvitenskapen for øvrig; historien fulgte en fastlagt utvikling fra mindre komplekse kulturformer til fremskritt og sivilisasjon. Nært sammenfallende med dette var også ideen om at gjenstandene kunne ordnes i evolusjonære sekvenser. Noen ble sett på som gjenlevninger etter en konservativ og tidløs kultur, andre ble tilskrevet verdi som symboler for menneskers visjoner, kreativitet og skaperkraft. Denne evolusjonistiske tenkningen kom ofte til uttrykk som en kulturell og nasjonalistisk selvhevdelse i møtet med urbefolkninger og fremmede kulturer. I Norge ble f.eks. Osebergskipet gjort til et symbol for både heltemot, fremskritt og oppfinnelse (Østigård 2001), mens etnografiske gjenstander ble stående som "minner" om en uskyldighet som var i ferd med å forsvinne (Rio 2002: 61). På denne måten kom gjenstandene til å bygge opp under en forestilling om at det eksisterte vesentlige utviklingsmessige forskjeller mellom oss (de siviliserte) og de uskyldige, eksotiske og usiviliserte andre (se Olsen 2000).

I denne artikkelen skal jeg se nærmere på hvilken rolle gjenstandene spilte i de tidlige museene, hvordan de etter hvert kom til å få

Mange museer har gjenstandssamlinger som inneholder flere hundre tusen gjenstander, men bare $5 \%$ av gjenstandene blir brukt i forskning og formidling. () Kulturhistorisk Museum, Universitetet i Oslo. Mårten Teigen.

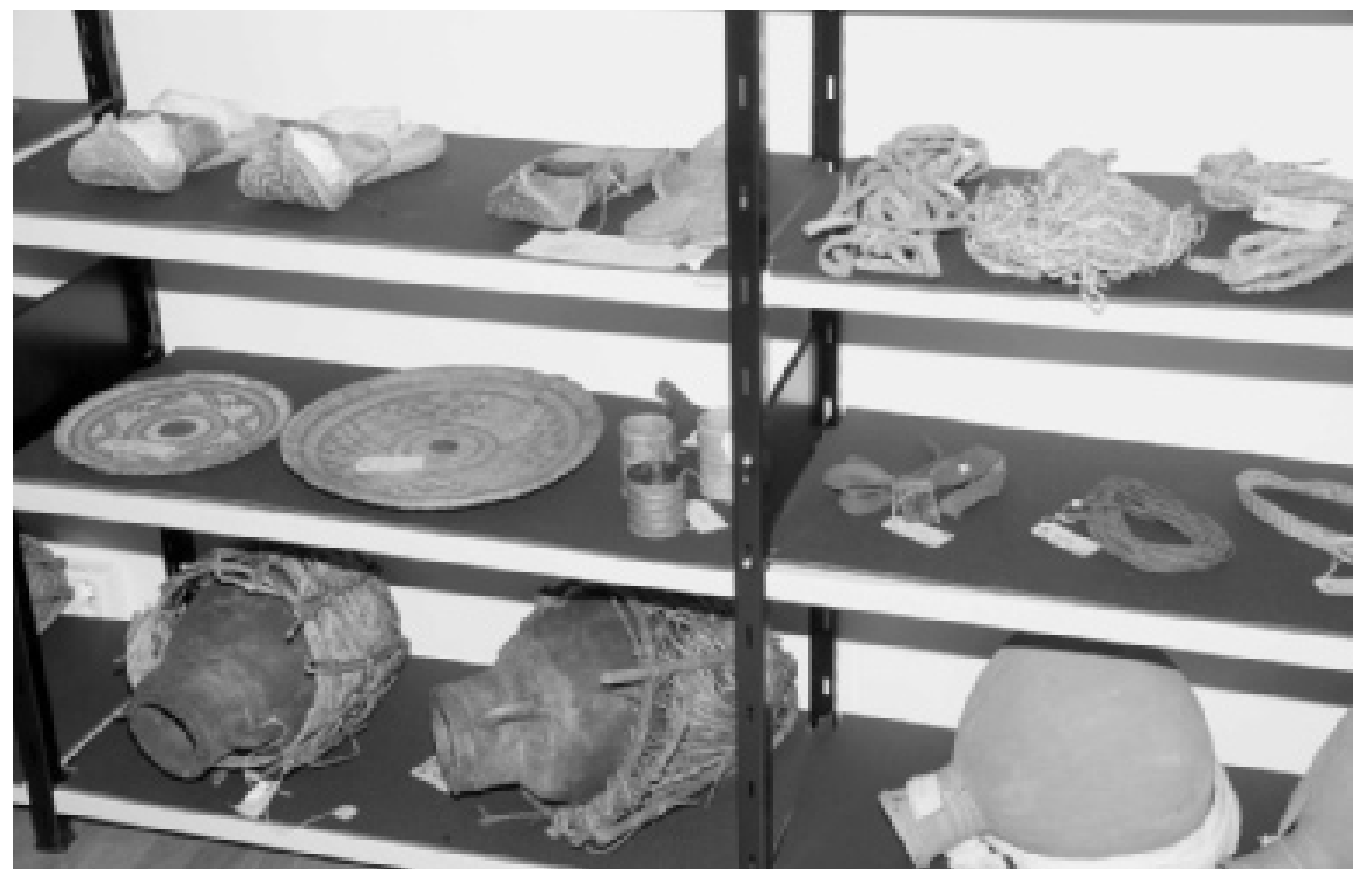


innskrenket betydning i formidlingssammenheng og hvilke utfordringer museene står ovenfor $\mathrm{i}$ forhold til det å skulle oppgradere statusen til gjenstander og styrke sin posisjon i forhold til andre medier.

\section{VITENSKAPEN OG DISKREDITERINGEN AF DET MATERIELLE}

Kuriositetskabinettene og museene ble grunnlagt i en tid hvor empirismen sto sterkt som et kunnskapsteoretisk ideal. Dette viste seg blant annet ved at gjenstander nedfelte seg som en kilde til vitenskapelig erkjennelse. Renessansekabinettene inneholdt biter av naturens mangfold. Ved å samle inn så mye som mulig av dette mangfoldet kunne man komme nærmere en forståelse av Gud. "Gud hadde skrevet sine signaturer, å forstå naturen var å tyde hans tegn, å lese hans tekst" (Broberg og Sörlin 1991: 6). Med modernismen kom iveren etter å sette naturen i system. Også her hadde samlingene en rolle å spille som vitenskapens forlengede arm (Broberg og Sörlin 1991: 6). I øynene til 1800-tallets evolusjonsteoretikere kunne museenes gjenstander plasseres på en evolusjonær akse som startet ved skapelsen og endte med fullendelse og perfeksjon.

Det er lett å se hvordan gjenstandene på denne måten kom til å bidra til - og ikke minst synliggjøre - utviklingen av moderne vitenskap. Likevel er det viktig å være klar over at de museale gjenstandene ble tilskrevet en verdi som forskningen verken før eller siden har tilkjent dem. Selv om nedvurderingen av det materielle til fordel for det mentale muligens har en tidlig spore hos Descartes (se Olsen 2004: 30), må gjenstandenes fallende betydning som vitenskapelig kilde først og fremst sees i sammenheng med vitenskapens utvik- ling på 1900-tallet og fremveksten av logisk skapene avskrev empirismen som kunnskapsteoretisk ideal og den logiske positivismen tilkjente teoretiske størrelser objektivitet gjennom kriterier for såkalt kognitivt meningsfulle utsagn, har gjenstandene i stor grad blitt behandlet som epifenomen. Innenfor den prosessuelle retningen, som dominerte arkeologien på 1960 - og 70- tallet, ble kritikken mot gjenstandsbaserte studier gjort til et stort retorisk og polemisk poeng. Kulturhistoriske arkeologer ble beskyldt for å drive med lite problemorientert forskning og for å tro at beskrivelser av data var et mål i seg selv. En tilsvarende nedvurdering av det materielle til fordel for det immaterielle fant sted i antropologi, men her ble studiet av materiell kultur neglisjert som forskningsfelt også etter at positivismen hadde forlatt den akademiske scenen. Dette kan ha sammenheng med en mer grunnleggende skepsis mot gjenstander innenfor faget som sådan. Antropologer har lenge stilt seg uforstående til nødvendigheten av å studere gjenstander, så lenge de har hatt mulighet til å drive med deltakende observasjon og kulturforståelse har vært målet for deres virksomhet. Gjenstandene har gitt assosiasjoner til en lite beundringsverdig (og uvitenskapelig) fortid og har i stor grad blitt behandlet som en annenrangs kilde til informasjon. Etter introduksjonen av ulike post-strukturalistiske, fenomenologiske og hermeneutiske perspektiv utover på 1980- og 90-tallet, har interessen for materielle kulturstudier $ø \mathrm{kt}$. Likevel mener Olsen (2004) at disse studiene ikke har hatt den materielle kulturen som sitt sentrale utgangspunkt (se også Andersson 2001: 131, Löfgren 1997). Fokus har vært rettet mot hvordan subjektene opplever og tolker den materielle verden, ikke hvordan materiell 


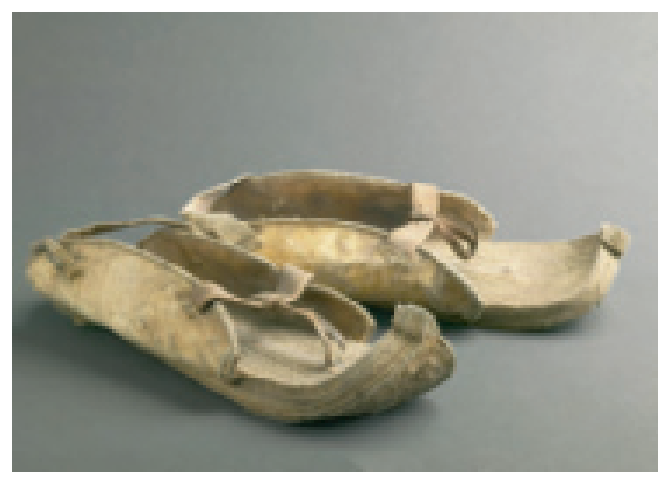

Sandaler av ler fra Somalia. Personlige eiendeler som sko og sandaler har i seg et stort potensial for formidling. Hvem var mannen som brukte disse sandalene? Nar levde han? Og hvordan så han ut? (C) Kulturhistorisk Museum, Universitetet i Oslo. Mårten Teigen.

kultur rent faktisk er medvirkende i konstitueringen av våre sosiale liv. Det synes med andre ord å være "liten sympati og forståelse for de kvaliteter og kompetanser som den materielle verden selv besitter - kvaliteter som blir effektive i vår konkrete og innfugete omgang med den" (Olsen 2004: 29).

\section{GJENSTANDER OG UTSTILLINGER: FRA MIDTPUNKT TIL PERIFERI}

Denne mistroiskheten ovenfor hva gjenstander kan bidra med, gjenspeiler seg også i måten utstillinger blir laget på. Gjenstanden er ikke lenger midtpunktet i utstillingen, men opptrer i rollen som bestanddel sammen med kulisser, bilder og tekst. Sånn sett er det ikke lenger gjenstanden selv, men helheten den inngår $i$, som er det budbringende elementet $i$ formidling. Selv om kimen til en slik de-sentrering (eller kontekstualisering) eksisterte så tidlig som på 1800-tallet (Ellenius og Won- ders 1991, Maure 2004: 62), er det først de siste tretti år at gjenstanden systematisk har blitt regissert inn i en ramme som har hatt til formål å skape en virkelighetsillusjon og en naturalistisk fortolkningskontekst. Motivasjonen for dette har selvsagt vært å legge til rette for en mer engasjerende og fengende formidlingsform (se Olsen 1997: 237). Hvis museene ikke kan tilby noe annet enn pent ordnede gjenstander i en monter, vil de ikke komme styrket ut av konkurransen med andre medier. Formålet med å skape et "naturlig" miljø rundt gjenstanden, har vært å servere et utfyllende bilde av de sammenhengene gjenstandene en gang har inngått $i$.

Introduksjonen av ulike postmoderne perspektiv har ikke bidratt til å nyansere dette bildet i nevneverdig grad. Selv om materielle kulturstudier står sentralt i mange postmoderne tilnærminger, får man snarere det inntrykk at gjenstandene har blitt ytterligere svekket som kilde. Det har sammenheng med at postmodernistene mener at det ikke skal være museenes oppgave å pålegge publikum endelige sannheter og objektive svar. Museene skal fremme debatt og oppmuntre de besøkende til å forholde seg kritisk til kunnskap. Dette er vel og bra, men hensikten med denne "nye" pedagogiske tilnærmingen faller bort når det viser seg at publikum ikke har noe faglig grunnlag for å tenke kritisk. Faktaplakatene som tidligere prydet veggen ved siden av gjenstanden, er byttet ut med dikt. Det finnes ingen fakta, for fakta er selv konstruert, men i det vakuumet som oppsto da plakaten ble fjernet, er gjenstanden fullstendig meningsløs. Den er ubetydelig, intetsigende og umyndiggjort som kilde. Dermed har vi kommet i den paradoksale situasjon at gjenstanden er flyttet tilbake til utstillingens midte, uten at den er i stand til å fortelle noe som helst. 
KAN ET SKJELETT KONKURRERE MOT EN "LEVENDE" DINOSAUR?

Resultatet av at den materielle kulturen har blitt diskreditert innenfor vitenskapen, er at det hersker en betydelig usikkerhet ved hva museumsgjenstander egentlig kan bidra med. Denne usikkerheten blir ikke mindre av at museene konkurrerer med en lang rekke medier (Internet, TV, kino, DVD, aviser, tidsskrifter o.l.), som kanskje er bedre egnet til formidling enn det museene er. Anders Johansen (2002: 193) har rett, når han sier at det sikkert var interessant å se et utstoppet dyr på museum, så lenge dette var eneste mulighet til å se dyret med egne øyne. I dag har de fleste barn sett realistiske og naturtro presentasjoner av dyr på TV. De har til og med sett "opptak" av dinosaurer som er så livaktige, at selv voksne har vanskeligheter med å forstå at disse kjempebeistene ikke lenger vandrer rundt på kloden. Mot dette fortoner museumsutstillingene med sine mange utstoppede dyr, gjenstander og plansjer seg som temmelig formålsløse. Hva skal vi egentlig med zoologiske museer, når dinosaurene er så nær oss, at de griser til kameralinsen med søle? Hvorfor skal vi stirre på en steinøks i en monter, når vi kan se "levende" neandertalere nedlegge kjempemammuter på TV? Det er legitimt å stille spørsmål ved om ikke museene, med sine gjenstandssamlinger, er i ferd med å bli utkonkurrert av det moderne billedmediets realisme (Johansen 2002: 194).

Til tross for disse relevante innvendingene og den betydelige usikkerheten som hersker ved gjenstandenes formidlingspotensial, blir innsamling, konservering og formidling av kunnskap knyttet til gjenstander fremdeles referert til som en sentral del av museenes virksomhet:
A museum is a non-profit making, permanent institution in the service of society and of its development, and open to the public, which acquires, conserves, researches, communicates and exhibits, for purposes of study, education and enjoyment, material evidence of people and their environment (ICOMs statutter).

Likevel åpnes det for at planetarier og vitensentre også kan karakteriseres som museer, selv om disse institusjonene ikke driver med museal formidling i tradisjonell forstand (se Nilsen 2003: 204). Med museal formidling forstår man dermed tilgjengeliggjøring av kunnskap, men det er ikke nødvendigvis et krav at denne kunnskapen skal være gjenstandsbasert.

Denne utviklingen, som går i retning av en bredere definert museal virksomhet, blir mer håndgripelig, hvis man ser den i sammenheng med kravene som i den senere tid har vært rettet mot museumssektoren: museene skal øke besøkstallet og forbedre sitt eget inntjeningsgrunnlag (Ashely-Smith 2005: 80, Olsen 1997: 239). De skal være forskningsinstitusjoner, formidlingsarenaer og politisk bevisste aktører. De skal fungere som kultur - og aktivitetshus, konsertscener, møtelokaler og som arenaer for debatt og opplysning. Omstillingen har aktualisert en identitetsproblematikk, som synliggjør de utfordringene som museene står ovenfor: nemlig å befeste sin rolle som kunnskapsleverandør i et marked, som domineres av en effektiv, omgripende og profesjonell medieindustri.

Til tross for at enkelte ser ut til å mene det motsatte, ligger ikke løsningen på dette problemet i å bli mindre museal. I stedet burde museene snu seg tilbake og forsøke å gjenskape det som var grunnlaget for kabinettenes og de første museenes suksess: nemlig erkjennelsen av at gjenstandene er en kilde til viten, 
34 beundring, kunnskap og begjær. Museet burde kort sagt bli en" leverandør av noe som nettopp det og ingen andre kan bidra med" (Johansen 2002: 193).

\section{GJenstandenes EMOSJONELLE POTENSIAL}

Argumentet her er altså, at museene vil tjene på å redefinere sin rolle med utgangspunkt i den mer tradisjonelle museale virksomheten. Forutsetningen for dette er selvsagt, at man erkjenner at gjenstander innehar et formidlingspotensial. Dette potensialet er først og fremst knyttet opp mot gjenstandenes biografiske kvaliteter; det at de har sine egne historier, at de har reist mellom mennesker og at de opptrer i menneskenes minner og fortellinger. Dette er en egenskap som ikke har kommet de masseproduserte gjenstandene til del. I følge filosofen Walter Benjamin skjedde det nemlig en endring i vårt forhold til ting under industrialismens og kapitalismens fremvekst. Tilgangen til billig arbeidskraft, dampkraft og elektrisitet gjorde, at gjenstander ble produsert $i$ et helt annet omfang enn før. De mistet sin individualitet og gikk over fra å være særegne håndverksprodukt til å bli varer på et marked. Men industrialiseringsprosessene bidro også til å øke interessen for museene, som i tillegg til sine mer vitenskapelige ambisjoner også hadde som formål å redde gjenstandene fra masseproduksjonens anonymiserende grep. I museene ble tingene gjort til gjenstand for en sentimental og nostalgisk dyrkelse, nettopp fordi de hadde en betydning som ikke var grunnet $i$ et nytteaspekt. Museet ble et opplevelsessenter det fremmedgjorte mennesket oppsøkte for å lindre følelsen av å ha mistet kontakten med tingene (Andersson 2001: 39-40).
Selv om dagens museer neppe bør prioritere å redde mennesker fra en industriell fortapelse, har de en enestående mulighet til å formidle kunnskap som berører oss emosjonelt. Erkjennelsen av at gjenstandene er innsvøpt i historie, og at de har sin egen biografi, bidrar til å skape emosjonelle bånd mellom mennesker og ting. Samtidig finnes det en temporær distanse som medvirker til å gi liv til fantasiene og sette følelsene i sving. Synet av en gammel sko kan f.eks. få oss til å tenke på menneskene som en gang har levd, på livets ubønnhørlige gang og vår egen forgjengelighet. På mange måter kan man si, at det er denne evnen til å kombinere en følelsesmessig nærhet med en temporær distanse, som utgjør det unike ved måten gjenstandene henvender seg på. "Auraen omgir tingene og lar dem beholde sin fjernhet samtidig som den tydeliggjør at det er tingene $\mathrm{i}$ sin annerledeshet som er $\mathrm{i}$ stand til å tale til oss" (Andersson 2001: 39). Ved å kombinere det nære og kjente med det som er atskilt fra oss i tid, har gjenstandene lagt til rette for en engasjert og levende formidlingsstrategi. Det er dette Mats Burström (2004: 27) sikter til, når han uttaler seg om tingenes "emosjonelle og refleksive potensial". Museene vil komme langt $\mathrm{i}$ å legitimere sin egen eksistens, hvis de klarer å slå øynene opp for dette potensialet og innrømme at de, i motsetning til f.eks. fjernsyn og Internet, har en mulighet til å formidle informasjon som i mye større grad berører oss emosjonelt.

\section{IMPLIKASJONER FOR FORMIDLING}

Gjenstanden henvender seg altså til et publikum på et emosjonelt plan, men den emosjonelle opplevelsen, man får ved synet av en gjenstand, har også i seg et potensial for læ- 
ring. Jo mer vi lar oss berøre av en gjenstand, desto større motivasjon har vi for å tilegne oss kunnskap og informasjon. Men læring og følelser står i et tilbakevirkende forhold til hverandre: hvis man ikke vet noe om en gjenstand, er det også vanskeligere å la seg berøre emosjonelt. Arkeologiske gjenstander vil for eksempel være relativt meningsløse for folk som ikke har kjennskap til arkeologi fra før. I et pedagogisk perspektiv er det derfor viktig at gjenstander ledsages av en tilgjengelig og informativ tekst (Serrell 1996). Teksten formidler en historie, som er nødvendig for å styrke det emosjonelle båndet mellom mennesker og ting. Bruken av tekster i museene har imidlertid vært et omstridt tema i lang tid. Mange mener at tekster bør erstattes av andre formidlingsmetoder (trykkskjermer og audioguider), som ikke er påtvingende og som det heller ikke er anstrengende å benytte seg av. Forestillingen om at publikum synes det er anstrengende å lese tekster, er imidlertid tuftet på en misforstått forestilling om at publikum ikke er interessert i kunnskap. Det er viktig å være klar over at publikum kommer til museene med forventninger om å få svar på sine spørsmål, og at fraværet av tilgjengelig tekst bidrar til å skape forvirring og frustrasjon.

Det kan imidlertid være vanskelig å få museumsdesignere og arkitekter til å forstå at gjenstander er med i utstillinger annet enn for estetikkens skyld. Man ser ofte at gjenstander plasseres i en sammenheng, hvor de først og fremst fremstår som estetiske objekt. Utstillingstekstene, som er til for å realisere gjenstandens informative potensial, oppfattes som en trussel mot renheten og estetikken i arkitektens design, og blir følgelig forvist og umyndiggjort. Slik fremstår gjenstanden mer som et kunstobjekt enn en kulturhistorisk kilde.
Konklusjonen her er at gjenstandsbasert formidling bare kan lykkes, hvis gjenstandene suppleres av tekster som er tilgjengelige både i innhold og form. Dette betyr ikke at museene skal være ensidig teoretisk i sin formidlingsstrategi. Museene har en enestående mulighet til å fornye og berike sitt repertoar gjennom lek og aktiv læring (Johansen 2002: 197). En slik aktivitetsrettet formidling er allerede godt implementert i museumspedagogikken, og trenger ingen utførlig beskrivelse her. Ved å la publikum ta på gjenstander (fortrinnsvis kopier) og å tillate dem å gjøre sine egne eksperiment (f.eks. lage pilspisser, sette sammen dinosaurskjelett, gjøre sine egne utgravninger osv.), legger man til rette for en kunnskapstilegnelse, som er personlig, engasjerende og genuint museal.

TILGJENGELIGGJøRING OG TILRETTELEGGING AV MUSEENES SAMLINGER

En formidling som i økende grad tar utgangspunkt i gjenstandene, krever en nyorientering i måten museene drives på. Mange museer har siden 1970-tallet hatt en økning i tilveksten av gjenstander på flere hundre prosent. Det sier seg selv at de ansatte ikke kan ha oversikt over samlinger som består av flere hundre tusen gjenstander. Med en årlig tilvekst på 1,5 \% vil samlingene fordobles i løpet av femti år (Keene 2005: 69). Prosjekter som har som formål å digitalisere samlingene blir derfor viktige, fordi de bidrar til å gjøre samlingene tilgjengelige $i$ et helt annet omfang enn før. Forhåpentligvis vil den økonomiske opptrappingsplanen som ligger innbakt $\mathrm{i}$ den norske museumsreformen, bidra til at også mindre museer kan digitalisere sine samlinger på sikt. Gjenstander som er tilgjengelige via nett, vil ganske sik- 
36 kert gi næring til viktige forskningsprosjekt. Museene må på sin side sikre at den kunnskapen som fremkommer med utgangspunkt i slike gjenstandsbaserte forskningsprosjekt, kanaliseres inn i utstillingsproduksjon og formidling. Dette kan f.eks. skje ved at museene ansetter egne fagfolk som har som sin primære oppgave å sikre kommunikasjon mellom fagmiljøene på den ene siden og utstillingsdesignere/museumspedagoger på den andre.

Å sikre god oversikt over samlingene er imidlertid ikke tilstrekkelig, hvis målsettingen er at gjenstandene skal brukes mer aktivt i forskning og formidling. I Norge finnes det ca. 800 små og store museer. Til tross for at innsamlingsviljen er stor, har de ansatte generelt liten kunnskap om gjenstandenes behov og få museer, bortsett fra universitetsmuseene, har råd til å ansette sine egne konservatorer (dette er riktignok i ferd med å endre seg ettersom museumsreformen, legger opp til at konsoliderte museer kan lage felles konserveringsverksteder). Slik både den norske Riksrevisjonens undersøkelse av bevaring og sikring av samlingerne ved fem statlige museer og det danske Kulturministeriets utredning om bevaring af kulturarven har vist, er situasjonen for mange kulturhistoriske gjenstander prekær. Jerngjenstander som har ligget tretti år i syreholdig, rosa krepp-papir, sverd fra vikingtiden som er så korrodert at de like gjerne kunne ha vært kastet, inntørket lær fra middelalderen som er ødelagt for all fremtidig analyse, skiferkniver fra steinalderen som har ferske brudd, fordi de har vært plassert i esker sammen med rullesteiner, møllspiste tekstiler, gjenstander med mugg osv. er av opplagte grunner ikke noe godt utgangspunkt for en gjenstandsbasert formidling. Derfor er det all grunn til å se positivt på REVITA-tiltak, som blant annet sikter mot å utarbeide bedre rutiner for vern av kulturhistoriske gjenstander i museer. ${ }^{2}$

Endelig må magasiner og emballasjeløsninger innrettes mot at gjenstandene faktisk skal stilles ut og forskes på. Gjenstandene bør for eksempel pakkes slik at de i størst mulig grad legger til rette for aktiv formidling (dvs. individuelt i esker, slik at de enkelt kan fraktes ut av magasinet på vei til nye utstillinger). Museumsmagasinet bør på sin side ligge i nærheten av et studierom, slik at forskere og studenter har mulighet til å bruke gjenstandene i forskningen sin. For ytterligere å stimulere interesse rundt gjenstandene, bør museene vurdere å opprette såkalte "innsynsmagasin", dvs. åpne magasin som tilgjengeliggjør større deler av samlingen for publikum.

\section{STRATEGIER FOR FRAMTIDEN}

Museene blir i stadig økende grad målt etter sin evne til omstilling. De blir møtt med krav om å ha en tydeligere profil og om å tilgjengeliggjøre seg selv og sin kunnskap. En av de største utfordringene museene står ovenfor er å befeste sin rolle som kunnskapsleverandør i et stadig mer mediestyrt marked. Argumentet i denne artikkelen har vært at museene bare kan komme styrket ut av konkurransen med andre medier, hvis se sentrerer større deler av sin virksomhet rundt gjenstander og våger å være mer museale i sin formidlingsform. Forutsetningen for at museene skal lykkes er, at de erkjenner, at gjenstandene innehar et formidlingspotensial, og at gjenstandene i kraft av å være minner fra en svunnet fortid, er $\mathrm{i}$ stand til å berøre oss emosjonelt.

Denne innrømmelsen har en mengde implikasjoner for måten museene drives på. For det første må museene styrke sin teoretiske og faktabaserte formidling. Museet skal ikke bare 
være et senter for opplevelse, men også et sted for læring. Konsekvensen av dette er at museumstekstene må ha en mer sentral rolle enn de har hatt til nå, siden de er avgjørende for at gjenstandene skal få realisert sitt formidlingspotensial. For det andre må vi søke å komme vekk fra en situasjon hvor bare $5 \%$ av gjenstandene anvendes i forskning og formidling. Museenes samlinger må tilrettelegges slik at de faktisk tåler å bli utstilt og forsket på. Debatten omkring sikring i museer dreier seg ikke kun om forebyggende tiltak mot tyveri, men i like stor grad om å sikre at kulturarven overlever i norske museer.

Jeg skal ikke gå videre med en presentasjon av praktiske tiltak her, men heller runde av med å gjenta noen av spørsmålene fra innledningen. Har museene en fremtid? Vil museene overleve i dagens mediesituasjon? Svaret på dette er ja. Museene har en fremtid og kan til og med styrke sin posisjon hvis de våger å være genuint museale $\mathrm{i}$ konkurransen med andre medier. Jeg håper å ha vist at dette forutsetter bevisstgjøring og aktiv innsats på alle trinn.

\section{NOTER}

1. Museumsreformen innebærer en opptrapping i bevilgningene fra staten på 121 millioner friske midler til drift, fordelt over en femårsperiode. Dette beløpet er noe mindre enn det som ble skissert i St.meld. nr. 22 (1999-2000), hvor museene ble lovet en samlet økning på 202 millioner kroner. Formålet med reformen er å legge til rette for faglig og administrativ konsolidering.

2. REVITA-planen ble lansert på bakgrunn av erfaringene fra den nederlandske Deltaplanen og den norske Trøndelagsundersøkelsen, og la opp til en rekke tiltak i forbindelse med utbedring av oppbevaringsforhold, forebyggende konservering og re- gistrering av restanser i norske museer (NOU 1996, se også Strømsnes 2003). I dag gjennomføres det REVITA-prosjekter på flere norske museer.

\section{LITTERATUR}

Andersson, D. T. : Tingenes tale, tingenes taushet. Solum Forlag, Oslo. 2001.

Ashely-Smith, J.: Storing objects for future use. I Magasinbygningens fysik og function. Postprint. Museumshøjskolen, Sorø. 2005.

Bennett, T. : The Birth of the Museum. History, theory, politics. Routledge, London og New York 1995.

Broberg, G. og Sörlin, S.: Umgänget med muserna. Tvärsnitt 1-2: 3-13. 1991.

Burström, M.: Archaeology and Existential Reflection. I Bolin (red.) The Interplay between Past and Present. Södertörn Archaeological Studies 1. 2002.

Ellenius, A. og Wonders, K.: Verklig eller blott målad? Tvärsnitt 1-2: 21-29. 1991.

Johansen, A.: Museet i dagens mediesituasjon. I Johansen, A. et. al (red.) Tingenes tale. Innspill til museologi, s 192-208. Universitetet i Bergen. 2002.

Keene, S.: Managing collections in store. I Magasinbygningens fysik og function. Postprint. Museumshøjskolen, Sorø. 2005.

Löfgren, O.: Scenes from a trobled marriage. Journal of Material Culture 2(1): 95-113. 1997.

Maure, M.: Bønder, ånder, dukker og skuespillere... Nordisk Museologi 1: 59-84. 2004.

Nilsen, G.: Brytninger mellom lokal og akademisk kulturminnekunnskap: en analyse av fortidsforestillinger i Nord-Troms og Loppa. Dr.gradsavhandling, Universitetet i Tromsø. 2003.

NOU (Norske offentlige utredninger).: 7. Museum. Mangfold, minne, møtested. 1996.

Olsen, B.: Fra ting til tekst. Teoretiske perspektiv i 
arkeologisk forskning. Universitetsforlaget, Oslo. 1997.

Olsen, B.: Bilder fra fortida? Representasjon av samisk kultur i samiske museer. Nordisk Museologi 2:13-30. 2000.

Olsen, B.: Momenter til et forsvar av tingene. Nordisk Museologi 2: 25-36. 2004.

Rio, K.: Eksotiske gjenstander og deres mu seumshistorie. I Johansen, A. et. al (red.) Tingenes tale. Innspill til museologi, s 65-73. Universitetet i Bergen. 2002.

Schulz, E.: Notes on the history of collecting and of museums. I Pearce, S. M (red.) Interpreting Objects and Collections. Routledge, London og New York. 1994.

Serrell, B.: Exhibit Labels - An Interpretive Approach. Alta Mira Press, Walnut Creek. 1996.

Strømsnes, A. M.: "Slik er det med museer..". Om museer og innsamlingsproblematikken. Upublisert hovedfagsoppgave, Universitetet i Bergen. 2003.

Østigård, T.: Norge uten nordmenn. En antinasjonalistisk arkeologi. Spartacus, Oslo. 2001.

\section{SUMMERY}

How do we revitalise artefacts as objects of fascination? The purpose of this paper is to address some of the challenges the museums are facing in the 21 st century. Today, museums are competing for people's leisure time against a plethora of information providers. These information providers offer new technologies and new educational opportunities in addition to aggressive commercial marketing. How should museums face up to these new conditions? Should they respond solely by embracing new technology? Or should they use these challenges to reflect on their own identity?
Traditionally, museums have chosen objects to constitute their principal point of reference. Over the past 10 to 15 years, however, many museums have reinvented themselves beyond recognition. They are not only places for visual and aesthetic display, but are also civically engaged institutions or places for entertainment, creativity and learning. Some museum workers tend to believe that traditional exhibitions are not powerful enough as a communication mode, and that the role of the museum should be modified to serve other needs. I am, however, convinced that museums should remain faithful to their own mission (although they should of course integrate new technology in their agenda and equip exhibitions with sound recordings, demonstrations, hands-on activities and so on to help contextualise the objects). The success of the 21 st-century museum is based on its ability to engage its audience through displays of objects, not by being just another digital enterprise. It is important to note, in this respect, that people respond to objects on an emotional level, and that museums have a far better opportunity to engage people on a personal basis than other media.

In order to facilitate access to the objects, the museums need to make sure that preservation conditions are monitored, since this is the single most important factor for the survival of collections. Unfortunately, a large percentage of the collections are stored in rooms that are damaging to the objects. If museums want to play a more substantial role in the future, they need to take their collections more seriously.

Kristine Orestad Sørgaard er arkeolog og ansatt på REVITA-prosjektet ved Kulturhistorisk Museum i Oslo. Email:k.o.sorgaard@khm.uio.no 